\title{
Olfactory Dysfunction: A Clinical Marker of COVID-19
}

\author{
Apar Pokharel ${ }^{1}$ \\ 'College of Medical Sciences, Chitwan, Nepal. \\ ABSTRACT
}

Due to the rapid spread of the SARS-CoV-2 virus, many health systems worldwide are overwhelmed, leading to the triggering of the scarcity of medical resources. The identification of indicators that require hospital admission help in the efficient allocation of medical resources. Olfactory impairment is also one of the indicators of COVID-19 infection. Many studies have analyzed olfactory dysfunction in COVID-19 with a variable prevalence rate but underreporting of this problem is very much likely as the problem is considered benign. Many scientific societies have stated that olfactory dysfunction is a frequent symptom of COVID-19 and have published recommendations for it.

Keywords: anosmia; olfactory dysfunction; SARS-CoV-2.

\section{INTRODUCTION}

The COVID-19 is an ongoing viral pandemic that started in December 2019 from Wuhan, Hubei province, China, and quickly spread to the rest of the world. ${ }^{1}$ World Health Organisation (WHO) named the disease COVID-19 on February 12, 2020. As of 10th September, 2020, WHO reports a total number of 27.9 million people have been diagnosed with COVID-19 infection, with 905 thousand deaths involving 214 countries and territories. ${ }^{2}$ COVID-19 disease is responsible for the longest pandemic since the $1918 \mathrm{H} 1 \mathrm{~N} 1$ influenza outbreak. ${ }^{3}$ Human-to-human transmission is occurring at an exponential rate, which has led to steep curves in the incidence of disease in many countries. ${ }^{4}$

According to clinical studies, fever, cough, dyspnea, sputum production, arthralgia, myalgia, diarrhea, headache, rhinorrhea, and sore throat are the most commonly reported clinical features.,6 Among these, fever and cough with Iymphocytopenia and groundglass opacity changes on chest computed tomography the main manifestations of COVID-19 patients. ${ }^{1}$ In severe infection, acute cerebrovascular diseases, skeletal muscle injury, and impaired consciousness have also been reported. ${ }^{7}$

However, recent studies have shown olfactory and gustatory dysfunctions as newer clinical features. People with loss of smell and taste are three times more likely to have contracted the virus if they have other symptoms described by the World Health
Organisation. ${ }^{8}$ Post viral olfactory dysfunction is a common phenomenon that occurs due to inflammatory reactions to the nasal mucosa and is accompanied by rhinorrhoea. However, olfactory dysfunction in COVID-19 can occur even without rhinorrhoea.9,10 The severity and prevalence of olfactory dysfunction among COVID-19 patients still remain unclear. We have searched databases like PubMed, Cochrane Clinical Trials, ScienceDirect, Lilacs, Scopus, and Google Scholar. This review summarizes various studies' findings on olfactory dysfunction during the COVID-19 pandemic, its pathophysiology, and strategies to cope with this problem.

\section{PATHOPHYSIOLOGY}

Post-viral upper respiratory tract infections (8-45\%), nasal sinus disease (7-56\%), head trauma (8-20\%), toxins/drugs (2-6\%), and congenital loss (0-4\%) are the leading causes of olfactory dysfunction seen in clinics of USA, Europe, and Japan. ${ }^{11}$ Viral upper respiratory tract infections are responsible for the cause of postviral anosmia. ${ }^{12,13}$ Post viral anosmia is more common in female and middle-aged and older individuals. ${ }^{14}$ Such anosmia has a favorable prognosis. ${ }^{12}$ Suzuki et al. found coronavirus, rhinovirus, parainfluenza virus, and Epstein-Barr virus in patients' nasal secretions suffering from post-viral olfactory disorders. ${ }^{9}$ Different kinds of viruses, including coronavirus as HCoV-229E,

Correspondence: Apar Pokharel, College of Medical Sciences, Chitwan, Nepal. Email: aparpokharel@hotmail.com, Phone: +977-9855058234. 
can cause post-viral olfactory loss. Post viral olfactory loss is usually of long duration, with $80 \%$ subjective recovery after one year of follow-up. ${ }^{15}$ In COVID-19, the anosmia is acute, lasting for one week. ${ }^{16-18}$

Seven different strains of coronavirus can cause human infection, namely Severe Acute Respiratory Syndrome Corona Virus-2 (SARS-CoV-2), Severe Acute Respiratory Syndrome Corona Virus (SARSCoV), Middle East Respiratory Syndrome Corona Virus (MERS-CoV), HCoV-NL63, HCoV-229E, HCoV-HKU1, and HCoV-OC43. ${ }^{19}$ SARS-CoV-2 is a 29,903 bp singlestranded RNA coronavirus. ${ }^{20}$ Both SARS-CoV and SARS-CoV-2 belong to the coronavirus family's betagenus and share an $82 \%$ similar genetic sequence. ${ }^{21}$ On studying the pathology of coronavirus infection using the rhesus macaques model, it was revealed that the primary pathogenic site for the SARS-CoV-2 virus was the nose and throat. The viral load in the patient's nasal cavity was higher than the pharynx. ${ }^{22}$

ACE-2 receptor inhibitor in the nasal mucosa participates in respiratory inflammatory diseases by regulating the level of inflammatory peptides like bradykinin. ${ }^{23}$ However, in COVID-19 patients, alteration of the sensation of smell is not accompanied by rhinitis and other inflammatory components. ${ }^{18,24}$ So, one hypothesis is that the transmission could damage the olfactory pathway by the virus. In 2006, Hwang et al. described a case of anosmia that persisted for two years post-SARS infection. ${ }^{25}$ In 2001, Schwob et al. and Youngentob et al., on examining the olfactory bulb of SARS-CoV patients, found an abnormal predominance of immature neurons, indicating accelerated turnover of cells. ${ }^{26,27}$ This reduction in neurons' lifespan is due to the loss of trophic support supplied by the olfactory bulb to the sensory neurons. ${ }^{26,27}$ In 2008, Netland et al. hypothesized that neuronal death in SARS-CoV infection occurs due to the production of interleukin- 6 (IL-6) under the stimulation of viral N-spike protein. ${ }^{28}$ However, various COVID-19 case series report a high recovery rate of olfactory function within two weeks of infection. ${ }^{18,29,30}$ In addition to this, the frequency of central nervous system symptoms is much lower than SARS-CoV infection. This suggests that the target of the COVID-19 virus may not be neurons but other supporting cells that express ACE-2 receptors like sustentacular cells, microvillar cells, Bowman's gland cells, horizontal basal cells, and olfactory bulb pericytes. $^{31}$

COVID-19, like SARS-CoV, infects cells through interactions between its spike (S) protein and ACE2 protein on target cells. ACE-2 binding affinity of COVID-19 spike protein ectodomain is $10-20$ fold higher than SARS-CoV spike protein. ${ }^{20}$ This interaction requires cleavage of $\mathrm{S}$-protein by cell surface protease TMPRSS2. On previously published data of bulk RNA-Seq data derived from the whole olfactory epithelium of humans, no genes for ACE-2 nor TMPRSS2 were detected in the mature olfactory sensory neuroepithelium. However, ACE-2 was seen in the sustentacular cells and horizontal basal cells. This shows that sustentacular cells and horizontal basal cells are potential targets of the COVID-19 virus. Sustentacular cells structurally support sensory neurons, phagocytose and/or detoxify potentially damaging agents and maintain local salt and water balance. Horizontal basal cells act as reserve stem cells, which get activated upon tissue damage. ${ }^{31}$

The SARS-CoV-2 virus can cause acute onset anosmia by damaging the olfactory epithelium. ${ }^{12} \mathrm{~A}$ possible mechanism is that viruses can use the olfactory nerve to enter into the central nervous system like influenza A virus, herpes virus, poliovirus, rabies virus, parainfluenza virus, adenovirus, and Japanese encephalitis virus. $^{10}$ SARS-CoV virus showed transneuronal penetration through the olfactory bulb in mouse models resulting in the rapid intracranial spread. ${ }^{32}$

\section{LITERATURE REVIEW}

Studies conducted in Spain, Italy, United Kingdom, Belgium, France, the United States, and Iran showed the prevalence of olfactory dysfunction in the range of 33.9 to $68 \%$. The studies were conducted through non-contact methods like online questionnaires and telephone interviews. However, an olfactory function test (OFT) was not done in these cross-sectional studies. ${ }^{8,29,33-35}$ OFT was used in a study done by Ottaviano et al., who reported hyposmia as a primary symptom in six COVID-19 patients. The six odor smell test confirmed hyposmia. ${ }^{36}$ Moein et al. used 40 odorant University of Pennsylvania Smell Identification Test. It concluded that $98 \%$ of COVID-19 subjects had some olfactory dysfunction, and only $35 \%$ of them were aware of this dysfunction before testing. 3 A study done by the Mayo clinic using artificial intelligence showed anosmia as one of the features of COVID-19 patients. It also showed that the prevalence of anosmia was 28.6 fold higher than in COVD-19 positive patients. ${ }^{37}$

Anosmia is one of the common symptoms of SARSCoV-2 infection. ${ }^{38}$ Klopfenstein et al. reported that out of 114 cases of COVID-19, 54 (47\%) presented with anosmia. Anosmia was seen 4.4 days after the onset of infection and lasted for 8.96 days. $98 \%$ of patients recovered within 28 days of infection. ${ }^{17}$ Luers et al. reported that anosmia was seen on the fourth day after the first symptom onset. ${ }^{39}$ Beltran-Corbellini et al. and Lee et al. reported that the duration of smell disorder lasted for seven days. They also reported that $67.7 \%$ of 
patients reported acute onset of anosmia. ${ }^{16,40}$ Moein et al. reported that only $35 \%$ of the patients were aware of olfactory dysfunction before their smell examination was done. ${ }^{3}$ Yan et al. found that olfactory dysfunction was ten times more common in COVID-19 positive cases than in COVID-19 negative controls. Both cases and controls have similar influenza-like symptoms. ${ }^{29}$ Yan et al. showed a temporal relationship of olfactory dysfunction with a resolution of overall clinical illness in the ambulatory population. ${ }^{29}$ Corbellini et al. suggested new-onset olfactory dysfunction is more frequent amongst COVID-19 than in other viral upper respiratory tract infections. ${ }^{40}$

Moein et al. reported fewer smokers in the COVID-19 cohort than in the control population. ${ }^{3}$ Similar findings were reported in studies done on Chinese and US people. ${ }^{41,42}$ It is hypothesized that smoking upregulates the expression of ACE-2 in upper airways, increasing the risk of coronavirus infection but paradoxically protects the host from acute lung injury. ${ }^{43}$ Smokers are less susceptible to olfactory dysfunction from industrial exposures to acrylate and methacrylate. ${ }^{44}$ Smoking also protect olfactory loss to some degree in Parkinson's disease. ${ }^{45}$ Further research is warranted to find the cause of the low frequency of involvement of COVID-19 positive smokers complaining of olfactory loss.

In a study done in the ambulatory population, patients with influenza-like symptoms and anosmia are 6 to 10 times more likely to test positive for COVID-19 infection. ${ }^{29,46} 59-86 \%$ of COVID-19 patients presented with self-reported olfactory loss. ${ }^{18,29,46}$ Moein et al. reported high olfactory dysfunction rates (98\%) on quantitative analysis of COVID-19 patients with only $35 \%$ self-reported olfactory loss. ${ }^{3}$ This discrepancy between quantitative and self-reported olfactory dysfunction might be due to the lack of awareness or hyposmia under-reporting. ${ }^{47}$ Another reason for decreased reporting might be more severe symptoms like respiratory distress among these patients. ${ }^{48}$ Some studies state that patients who self-reported their olfactory loss usually have a milder form of the disease. Self-reported olfactory loss can be used as one indicator to risk-stratify patients for early determination and intervention among COVID-19 patients. ${ }^{48}$

A high incidence rate of olfactory dysfunction is reported in European and American countries compared to the Chinese population. ${ }^{17,49}$ Mao et al. reported an incidence of olfactory dysfunction to be around $5.1 \%$ in the COVID-19 positive Chinese population. ${ }^{7}$ Several reasons might be the cause of this difference. First is the mutation of the SARS-CoV-2 virus resulting in different genotypes. The $A$ and $C$ genotypes of the SARS-CoV-2 virus are more commonly seen among
Europeans and Americans, and the B genotype is more commonly seen in the East Asian population. ${ }^{50}$ The high pathogenicity of $A$ and $C$ strain for nasal cavity epithelium might cause a high prevalence of the olfactory disorder. The second reason might be that susceptibility differences among different human races might cause a difference in the prevalence of olfactory dysfunction among different races. A third reason is that people were more concerned about the primary life-threatening conditions during the outbreak in China, and the olfactory symptoms were overlooked and, therefore, under-reported. These are assumptions, and future research is warranted on this topic. ${ }^{51}$

An internet-based tool called Google Trends (GT) showed an abnormal elevation of anosmia topic search. Compared to the first week of March 2020, the search for anosmia topic had increased by $100 \%$ by the last week of March 2020. At present, by the second week of September 2020, the "Covid Anosmia" topic is around 33\% more searched compared to the first week of March. ${ }^{52}$ Gane et al. revealed a strong correlation between daily research volumes in Covid anosmia topic and the number of COVID-19 patients. ${ }^{53}$

\section{PERSPECTIVES FROM OTOLARYNGOLOGY}

Prof. Claire Hopkins did the first official emphasis on anosmia as an early symptom of COVID-19 infection on March 21, 2020.54 American academy of otolaryngology-head and neck surgery also released a statement mentioning that anosmia with dysgeusia can be seen in COVID-19 patients. ${ }^{55}$ American Academy of Otolaryngology-Head and Neck Surgery (AAO-HNS) also established the COVID-19 Anosmia Reporting Tool for Clinicians to allow healthcare providers to report olfactory dysfunction related to COVID-19 cases systematically. ${ }^{55}$ The increased number of cases with olfactory dysfunction in COVID-19 patients prompted organizations like the American Academy of Otolaryngology-Head and Neck Surgery and ENT UK to recommend the inclusion of sudden-onset loss of smell and/or taste as part of the diagnostic criteria for COVID-19 disease, as has now been done by the CDC. ${ }^{54-56}$

These organizations recommend that recent-onset of olfactory dysfunction alone is a sufficient symptom for self-isolation. Medical staff must use personal protective equipment (PPE) while evaluating patients with this clinical problem. Infected respiratory droplets from COVID-19 patients can get transmitted through the nose and mouth. Contact transmission by hands can also occur through virus deposited surfaces. ${ }^{57}$ Researchers have also suggested that the SARS-CoV-2 virus can transmit via aerosols. 58 During this pandemic 
period, routine appointments must be delayed or postponed to decrease the chance of virus infection of patients or healthcare professionals. Except for emergency conditions, online telemedicine is the best option for the reduction of COVID-19 cross-infection. ${ }^{59}$

\section{FUTURE DIRECTION}

Three areas of future research are there. First, clinical data on a large cohort of the population is needed to find the frequency and recovery time of anosmia in COVID-19 infection. Second, any correlation between the nasopharyngeal viral load and the severity of olfactory dysfunction must also be investigated. Lastly, histopathological analysis of the olfactory system can also be done in patients who died of COVID-19 infection.

\section{CONCLUSIONS}

Chemosensitive disorders like loss of olfaction is a frequent symptom of COVID-19 patients. The identification of paucisymptomatic patients is vital to manage the COVID-19 health crisis. In many centers, patients present with anosmia and ageusia with fever (>37.5) as onset symptoms are detected. Early identification of such conditions can break the chain of transmission. During the COVID-19 pandemic, attention has been given to the infected patients and frontline responders, with little attention being given to the hidden iceberg of suspected COVID-19 cases that are not yet in hospital. As widespread population testing is not possible in many countries, it is of utmost importance to identify all symptoms of COVID-19 so that a suspected case can self-isolate himself and prevent the spreading of disease. Anosmia could be used as a screening tool to identify potential cases that could be instructed to self-isolate.

Conflict of Interest: None.

\section{REFERENCES}

1. Guan W-J, Ni Z-Y, Hu Y, Liang W-H, Ou C-Q, He J-X, et al. Clinical Characteristics of Coronavirus Disease 2019 in China. N Engl J Med. 2020 30;382(18):1708-20. [PubMed | Full Text | DOI]

2. Coronavirus Update (Live): $28,177,569$ Cases and 910,610 Deaths from COVID-19 Virus Pandemic - Worldometer [Internet]. [cited 2020 Sep 10]. Available from: https:// www.worldometers.info/coronavirus/

3. Moein ST, Hashemian SM, Mansourafshar B, Khorram-Tousi A, Tabarsi P, Doty RL. Smell dysfunction: a biomarker for COVID-19. Int Forum Allergy Rhinol. 2020;10(8):944-50. [PubMed $\mid$ Full Text $\mid \underline{\text { DOI] }}$

4. Wu Y-C, Chen C-S, Chan Y-J. The outbreak of COVID-19: An overview. J Chin Med Assoc JCMA. 2020;83(3):217-20. [PubMed $\mid$ Full Text $\mid \underline{\text { DOI] }}$

5. Young BE, Ong SWX, Kalimuddin S, Low JG, Tan SY, Loh J, et al. Epidemiologic Features and Clinical Course of Patients Infected With SARS-CoV-2 in Singapore. JAMA. 2020 Apr 21;323(15):1488-94. [PubMed | Full Text | DOI]

6. Wan S, Xiang Y, Fang W, Zheng Y, Li B, Hu Y, et al. Clinical features and treatment of COVID-19 patients in northeast Chongqing. J Med Virol. 2020;92(7):797-806. [PubMed | Full $\underline{\text { Text }}$ | DOI]

7. Mao L, Jin $\mathrm{H}$, Wang $\mathrm{M}, \mathrm{Hu} \mathrm{Y}$, Chen $\mathrm{S}, \mathrm{He} \mathrm{Q}$, et al. Neurologic manifestations of hospitalized patients with coronavirus disease 2019 in Wuhan, China. JAMA Neurol. 2020;77(6):683-90. [PubMed | Full Text | DOI]

8. Menni C, Valdes A, Freydin MB, Ganesh S, Moustafa JE-S, Visconti A, et al. Loss of smell and taste in combination with other symptoms is a strong predictor of COVID-19 infection. MedRxiv. 2020. [Full Text | DOI]
9. Suzuki M, Saito K, Min W-P, Vladau C, Toida K, Itoh H, et al. Identification of viruses in patients with postviral olfactory dysfunction. The Laryngoscope. 2007 Feb;117(2):272-7. [PubMed | Full Text | DOI]

10. van Riel D, Verdijk R, Kuiken T. The olfactory nerve: a shortcut for influenza and other viral diseases into the central nervous system. J Pathol. 2015 Jan;235(2):277-87. [PubMed | Full Text | DOI]

11. Nordin S, Brämerson A. Complaints of olfactory disorders: epidemiology, assessment and clinical implications. Curr Opin Allergy Clin Immunol. 2008 Feb;8(1):10-5. [PubMed | DOI]

12. Hummel T, Whitcroft KL, Andrews P, Altundag A, Cinghi C, Costanzo RM, et al. Position paper on olfactory dysfunction. Rhinol Suppl. 2017;54(26):1-30. [PubMed | Full Text | DOI]

13. Welge-Lüssen A. Re-establishment of olfactory and taste functions. GMS Curr Top Otorhinolaryngol Head Neck Surg. 2005;4:Doc06. [PubMed | Full Text]

14. Jafek BW, Murrow B, Michaels R, Restrepo D, Linschoten M. Biopsies of human olfactory epithelium. Chem Senses. 2002 Sep;27(7):623-8. [uued | Full Text]

15. Lee DY, Lee WH, Wee JH, Kim J-W. Prognosis of postviral olfactory loss: follow-up study for longer than one year. Am J Rhinol Allergy. 2014 Oct;28(5):419-22. [라Med | DOI]

16. Lee Y, Min P, Lee S, Kim SW. Prevalence and Duration of Acute Loss of Smell or Taste in COVID-19 Patients. J Korean Med Sci. 2020 May 11;35(18):e174. [PubMed | Full Text | DOI]

17. Klopfenstein T, Kadiane-Oussou NJ, Toko L, Royer P-Y, Lepiller Q, Gendrin V, et al. Features of anosmia in COVID-19. Med Mal Infect. 2020 Aug;50(5):436-9. [PubMed | Full Text | DOI] 
18. Lechien JR, Chiesa-Estomba CM, De Siati DR, Horoi M, Le Bon SD, Rodriguez A, et al. Olfactory and gustatory dysfunctions as a clinical presentation of mild-to-moderate forms of the coronavirus disease (COVID-19): a multicenter European study. Eur Arch Oto-Rhino-Laryngol. 2020 Aug;277(8):2251-61. [PubMed | Full Text | DOI]

19. Wu Y, Xu X, Chen Z, Duan J, Hashimoto K, Yang L, et al. Nervous system involvement after infection with COVID-19 and other coronaviruses. Brain Behav Immun. 2020;87:18-22. [PubMed $|\underline{\text { Full Text }}| \underline{\text { DOI] }}$

20. Baig AM, Khaleeq A, Ali U, Syeda H. Evidence of the COVID-19 Virus Targeting the CNS: Tissue Distribution, Host-Virus Interaction, and Proposed Neurotropic Mechanisms. ACS Chem Neurosci. 2020 01;11(7):995-8. [PubMed | Full Text $\mid \underline{\text { DOI] }}$

21. Yeo C, Kaushal S, Yeo D. Enteric involvement of coronaviruses: is faecal-oral transmission of SARS-CoV-2 possible? Lancet Gastroenterol Hepatol. 2020;5(4):335-7. [PubMed | Full Text $\mid \underline{\text { DOI] }}$

22. Rockx B, Kuiken T, Herfst S, Bestebroer T, Lamers MM, Oude Munnink BB, et al. Comparative pathogenesis of COVID-19, MERS, and SARS in a nonhuman primate model. Science. 2020 29;368(6494):1012-5. [PubMed | Full Text | DOI]

23. Ohkubo K, Lee $\mathrm{CH}$, Baraniuk JN, Merida M, Hausfeld JN, Kaliner MA. Angiotensin-converting enzyme in the human nasal mucosa. Am J Respir Cell Mol Biol. 1994 Aug;11(2):173-80. [PubMed | DOI]

24. Vaira LA, Salzano G, Deiana G, De Riu G. Anosmia and Ageusia: Common Findings in COVID-19 Patients. The Laryngoscope. 2020;130(7):1787. [PubMed | Full Text | DOI]

25. Hwang C-S. Olfactory neuropathy in severe acute respiratory syndrome: report of A case. Acta Neurol Taiwanica. 2006 Mar;15(1):26-8. [PubMed | Full Text | DOI]

26. Schwob JE, Saha S, Youngentob SL, Jubelt B. Intranasal inoculation with the olfactory bulb line variant of mouse hepatitis virus causes extensive destruction of the olfactory bulb and accelerated turnover of neurons in the olfactory epithelium of mice. Chem Senses. 2001 Oct;26(8):937-52. [PubMed | Full Text | DOI]

27. Youngentob SL, Schwob JE, Saha S, Manglapus G, Jubelt B. Functional consequences following infection of the olfactory system by intranasal infusion of the olfactory bulb line variant (OBLV) of mouse hepatitis strain JHM. Chem Senses. 2001 Oct;26(8):953-63. [PubMed | Full Text | DOI]

28. Netland J, Meyerholz DK, Moore S, Cassell M, Perlman S. Severe acute respiratory syndrome coronavirus infection causes neuronal death in the absence of encephalitis in mice transgenic for human ACE2. J Virol. 2008 Aug;82(15):7264-75. [PubMed | Full Text $\mid \underline{\text { DOI] }}$

29. Yan $\mathrm{CH}$, Faraji F, Prajapati DP, Boone CE, De Conde AS. Association of chemosensory dysfunction and COVID-19 in patients presenting with influenza-like symptoms. Int Forum Allergy Rhinol. 2020;10(7):806-13. [PubMed | Full $\underline{\text { Text }} \mid \underline{\text { DOI] }}$

30. Vaira LA, Deiana G, Fois AG, Pirina P, Madeddu G, De Vito A, et al. Objective evaluation of anosmia and ageusia in COVID-19 patients: Single-center experience on 72 cases. Head Neck. 2020;42(6):1252-8. [PubMed | Full Text | DOI]

31. Brann DH, Tsukahara T, Weinreb C, Lipovsek M, Van den Berge $\mathrm{K}$, et al. Non-neuronal expression of SARS-CoV-2 entry genes in the olfactory system suggests mechanisms underlying COVID-19-associated anosmia. Sci Adv. 2020 Jul 31;6(31):eabc5801. [PubMed | Full Text | DOI]

32. Jang Y, Son HJ, Lee S, Lee EJ, Kim TH, Park SY. Olfactory and taste disorder: The first and only sign in a patient with SARS-CoV-2 pneumonia. Infect Control Hosp Epidemiol. 2020 Sep;41(9):1103. [uued | Full Text | DOI]

33. Giacomelli A, Pezzati L, Conti F, Bernacchia D, Siano M, Oreni L, et al. Self-reported Olfactory and Taste Disorders in Patients with Severe Acute Respiratory Coronavirus 2 Infection: A Cross-sectional Study. Clin Infect Dis Off Publ Infect Dis Soc Am. 2020 28;71(15):889-90. [PubMed | Full Text | DOI]

34. Bagheri SH, Asghari A, Farhadi M, Shamshiri AR, Kabir A, et al. Coincidence of COVID-19 epidemic and olfactory dysfunction outbreak in Iran. Med J Islam Repub Iran. 2020 Jun 15;34:62. [PubMed | Full Text | DOI]

35. Spinato G, Fabbris C, Polesel J, Cazzador D, Borsetto D, Hopkins C, et al. Alterations in Smell or Taste in Mildly Symptomatic Outpatients With SARS-CoV-2 Infection. JAMA. 2020 May 26;323(20):2089-90. [PubMed | Full Text I DOI]

36. Ottaviano G, Carecchio M, Scarpa B, Marchese-Ragona R. Olfactory and rhinological evaluations in SARS-CoV-2 patients complaining of olfactory loss. Rhinology. 2020 Aug 1;58(4):400-1. [PubMed | DOI]

37. Wagner T, Shweta F, Murugadoss K, Awasthi S, Venkatakrishnan AJ, et al. Augmented curation of clinical notes from a massive EHR system reveals symptoms of impending COVID-19 diagnosis. Elife. 2020 Jul 7;9:e58227. [PubMed | Full Text | DOI]

38. Heidari F, Karimi E, Firouzifar M, Khamushian P, Ansari R, Mohammadi Ardehali M, et al. Anosmia as a prominent symptom of COVID-19 infection. Rhinology. 2020 Jun 1;58(3):302-3. [PubMed | DOI]

39. Luers JC, Rokohl AC, Loreck N, Wawer Matos PA, Augustin $\mathrm{M}$, et al. Olfactory and Gustatory Dysfunction in Coronavirus Disease 19 (COVID-19). Clin Infect Dis. 2020 May 1:ciaa525. [PubMed | Full Text $\mid \underline{\text { DOI] }}$

40. Beltrán-Corbellini Á, Chico-García JL, Martínez-Poles J, Rodríguez-Jorge F, Natera-Villalba E, et al. Acute-onset smell and taste disorders in the context of COVID-19: a pilot multicentre polymerase chain reaction based case-control study. Eur J Neurol. 2020 Apr 22:10.1111/ene.14273. [ㅍull Text]

41. Zhang J-J, Dong X, Cao Y-Y, Yuan Y-D, Yang Y-B, Yan Y-Q, et al. Clinical characteristics of 140 patients infected with SARS-CoV-2 in Wuhan, China. Allergy. 2020;75(7):1730-41. [PubMed | Full Text | DOI]

42. Preliminary Estimates of the Prevalence of Selected Underlying Health Conditions Among Patients with Coronavirus Disease 2019- United States, February 12-March 28, 2020 | MMWR [Internet]. [cited 2020 Sep 10]. Available 
from: https://www.cdc.gov/mmwr/volumes/69/wr/ mm6913e2.htm

43. Leung JM, Yang CX, Tam A, Shaipanich T, Hackett T-L, Singhera GK, et al. ACE-2 expression in the small airway epithelia of smokers and COPD patients: implications for COVID-19. Eur Respir J. 2020;55(5);2000688. [랄ed | Full Text $\mid$ DOI]

44. Schwartz BS, Doty RL, Monroe C, Frye R, Barker S. Olfactory function in chemical workers exposed to acrylate and methacrylate vapors. Am J Public Health. 1989 May;79(5):613-8. [ubMed | Full Text | DOI]

45. Sharer JD, Leon-Sarmiento FE, Morley JF, Weintraub D, Doty RL. Olfactory dysfunction in Parkinson's disease: Positive effect of cigarette smoking. Mov Disord Off J Mov Disord Soc. 2015 May;30(6):859-62. [uuMed | Full Text | DOI]

46. Menni C, Valdes AM, Freidin MB, Sudre CH, Nguyen LH, Drew DA, et al. Real-time tracking of self-reported symptoms to predict potential COVID-19. Nat Med. 2020;26(7):1037-40. [PubMed | Full Text | DOI]

47. Wehling E, Nordin S, Espeseth T, Reinvang I, Lundervold AJ. Unawareness of olfactory dysfunction and its association with cognitive functioning in middle aged and old adults. Arch Clin Neuropsychol. 2011 Apr;26(3):260-9. [PubMed | Full Text | DOI]

48. Yan $\mathrm{CH}$, Faraji F, Prajapati DP, Ostrander BT, DeConde AS. Self-reported olfactory loss associates with outpatient clinical course in COVID-19. Int Forum Allergy Rhinol. 2020;10(7):821-31. [PubMed | Full Text | DOI]

49. Lovato A, de Filippis C. Clinical Presentation of COVID-19: A Systematic Review Focusing on Upper Airway Symptoms. Ear Nose Throat J. 2020 Nov;99(9):569-76. [PubMed | Full Text $\mid \underline{D O I}]$

50. Forster P, Forster L, Renfrew C, Forster M. Phylogenetic network analysis of SARS-CoV-2 genomes. Proc Natl Acad Sci USA. 2020 April;117(17):9241-3. [PubMed | Full Text | DOI]
51. Meng X, Deng Y, Dai Z, Meng Z. COVID-19 and anosmia: A review based on up-to-date knowledge. Am J Otolaryngol. 2020 Oct;41(5):102581. [uuMed | Full Text | DOI]

52. Google Trends [Internet]. Google Trends. [cited 2020 Sep 10]. Available from: https://trends.google.com/trends/ explore?q= $\mathrm{covid} \% 20$ anosmia\&geo $=\mathrm{US}$

53. Gane SB, Kelly C, Hopkins C. Isolated sudden onset anosmia in COVID-19 infection. A novel syndrome? Rhinology. 2020 Jun 1;58(3):299-301. [PubMed | DOI]

54. Hopkins PC, Kumar PN. Loss of sense of smell as marker of COVID. [cited 2020 Sep 10]; Available from: https:// www.entuk.org/sites/default/files/files/Loss $\% 20$ of $\% 20$ sense $\% 20$ of $\% 20$ smell $\% 20$ as $\% 20$ marker $\% 20$ of $\% 20$ COVID. pdf. [Full Text]

55. AAOHNS. Anosmia, Hyposmia, and Dysgeusia Symptoms of Coronavirus Disease, 22 March 2020. 2020. Available from: https://www.entnet.org/content/aao-hns-anosmia-hyposmia-and-dysgeusia-symptoms-coronavirus-disease. [ㅍull Text]

56. Whitcroft KL, Hummel T. Olfactory Dysfunction in COVID-19: Diagnosis and Management. JAMA. 2020 Jun 23;323(24):2512-4. [PubMed | Full Text | DOI]

57. van Doremalen N, Bushmaker T, Morris DH, Holbrook MG, Gamble A, Williamson BN, et al. Aerosol and Surface Stability of SARS-CoV-2 as Compared with SARS-CoV-1. N Engl J Med. 2020 16;382(16):1564-7. [PubMed | Full Text | DOI]

58. Liu Y, Ning Z, Chen Y, Guo M, Liu Y, Gali NK, et al. Aerodynamic analysis of SARS-CoV-2 in two Wuhan hospitals. Nature. 2020;582(7813):557-60. [PubMed | Full $\underline{\text { Text }} \mid \underline{\text { DOI] }}$

59. Meng X, Dai Z, Hang C, Wang Y. Smartphone-enabled wireless otoscope-assisted online telemedicine during the COVID-19 outbreak. Am J Otolaryngol. 2020 Jun;41(3):102476. [PubMed | Full Text | DOI] 